Article

\title{
Spiritual Leadership: Meaning in the Sustainable Workplace
}

\author{
Joanna Samul \\ Department of Management, Finance and Economy, Bialystok University of Technology, Wiejska 45A Street, \\ 15-351 Bialystok, Poland; j.samul@pb.edu.pl
}

Received: 19 November 2019; Accepted: 26 December 2019; Published: 29 December 2019

\begin{abstract}
The topic of leadership enjoys unflagging interest among management theorists and practitioners. One of the trends that arose in the 1990s is spiritual leadership. Some authors have pointed out the importance of spiritual leadership is to create a sustainable workplace for employees. Thus, there is a need to present the achievements of academic knowledge in this topic. The aim of the paper is to synthesize research in the emerging spiritual leadership theory and its importance for the creation of a sustainable workplace. This study explores the concept of spiritual leadership and proposes a conceptual model of spiritual leadership within the context of the sustainability of the workplace. The study is based on a literature review and bibliometric analysis of 373 publications from the Scopus database, spanning the period from 1980 to 2019. The findings obtained indicate that the development of the spiritual leadership theory is relevant and applicable to the creation and maintenance of a sustainable workplace for employees.
\end{abstract}

Keywords: spiritual leadership; workplace; sustainability

\section{Introduction}

Interest in the topic of leadership in an organization is constantly growing, as well as the search for the conditions of successful leadership. Based on this search for the conditions of successful leadership, many leadership theories have emerged: the Great Man theory with an attempt to answer the question "who a leader is"; behavioral theory with "what a leader does"; contingency theory with "where does leadership happen or occur"; and transactional leadership, transformational leadership, and other types of leadership with "what does a leader think about, mind, and do" ([1], p. 2). A lot of concepts have been developed that make up these theories. The reason for these theories and concepts is to search for the most effective leadership style. However, the main theories narrowly focus on one side of leadership—on traits, abilities, skills, behaviors, or contextual factors. Thus, an attempt to find the success of a leader is constantly undertaken.

Since the 1980s, leadership theories have given much emphasis on emotional, ethical, and authentic aspects of leadership, which were usually ignored in leadership literature [2]. Currently, this has started to be established at the centre of consideration [3]. In the mid 1990s, many studies were focused on spirituality issues. First, this topic was undertaken in the context of religion. Then, this was extended to management and organizational science. The aim of combining spirituality with leadership and workplace was to find a solution for the ills of modern society [4]. The effect of spirituality on a person's ability to lead others has been studied. Many research studies have shown that influence through vision, values, and relationships is better than influence through fear, power, and control $[5,6]$. Moreover, transition from a leadership-centred workplace to a human-centered workplace has led to the emergence of different dimensions of spiritual leadership as prominent in today's world. Around the year 2000, a concept of spiritual leadership emerged as a result of growing attention among scholars on the search for a positive and sustainable workplace. Some studies showed that spiritual individuals 
have a tendency to focus on sustainability and make contributions beyond their own interests [7], and workplace spirituality contributes effectively to the sustainable behavior of individuals [8]. However, there is a little research on how spiritual leadership has affected sustainability in the workplace [9-11].

To reduce this gap in the literature, this paper uses the concept of spiritual intelligence and explores its significance for sustainability in the workplace. Firstly, this study presents the achievement in academic knowledge of the emerging concept of spiritual leadership in management science. Secondly, this study points out the significance of spiritual leadership for spirituality and sustainability in the workplace. Thirdly, it also offers a conceptual model of the impact of spiritual leadership on the sustainable workplace through a spiritual workplace. The article concludes with findings and discussions of further directions for the spiritual leadership theory for sustainable workplace development.

\section{Methods}

A literature review of scholarly articles, books, and other sources relevant to the area of spiritual leadership was conducted. This method was chosen because spiritual leadership is a relatively new topic in leadership literature. A literature review addresses new or emerging topics that would benefit from a holistic conceptualization and synthesis of the literature ([12], p. 47). Literature review is important because before conducting research, scholars should be able to understand what has been done before [13].

The search for paper reviews was done on 10 October 2019 on Scopus, a large database of academic texts. The searched keyword was "spiritual leadership" in titles, abstracts, and author keywords. The category of "Business, Management, and Accounting" was used in order to contain only research results that are about spiritual leadership in management science. As a result, 373 publications from the year 1980 (when the first publication was recorded in the database) to the present year 2019 were identified and were included in the review. However, the literature review was not limited to these publications, but also included the other relevant papers and books that appeared during the search. The literature review was carried out by compiling publications from the searched items of spiritual leadership and workplace spirituality.

The bibliometric analysis of the 373 publications included trend and cluster analyses. Trend analysis allowed for the presentation of the main trends and changes in the publications of spiritual leadership. Identification of the number of publications with consideration for the year of publication, and the most popular journals that are related to spiritual leadership in management science, was performed. For cluster analysis, the VOSviewer method was used. VOSviewer is a method for quantitative analysis of textual data and for constructing and viewing bibliometric maps [14]. The VOSviewer software helped to combine the analyzed set of data into clusters, which allowed for the identification of the main areas of research.

\subsection{The Profile of the Reviewed Publications}

In total, 373 articles were analyzed. The first publication about spiritual leadership was recorded in 1980 on the Scopus database, the next one was recorded in 1989, and then another in 1994. Since then, the number of spiritual leadership articles has increased, as shown in Figure 1. Although in 2018, the number of publications about spiritual leadership is observed to decrease slightly (as shown in Figure 1), the entire graph can be characterized as a cyclical increase. 


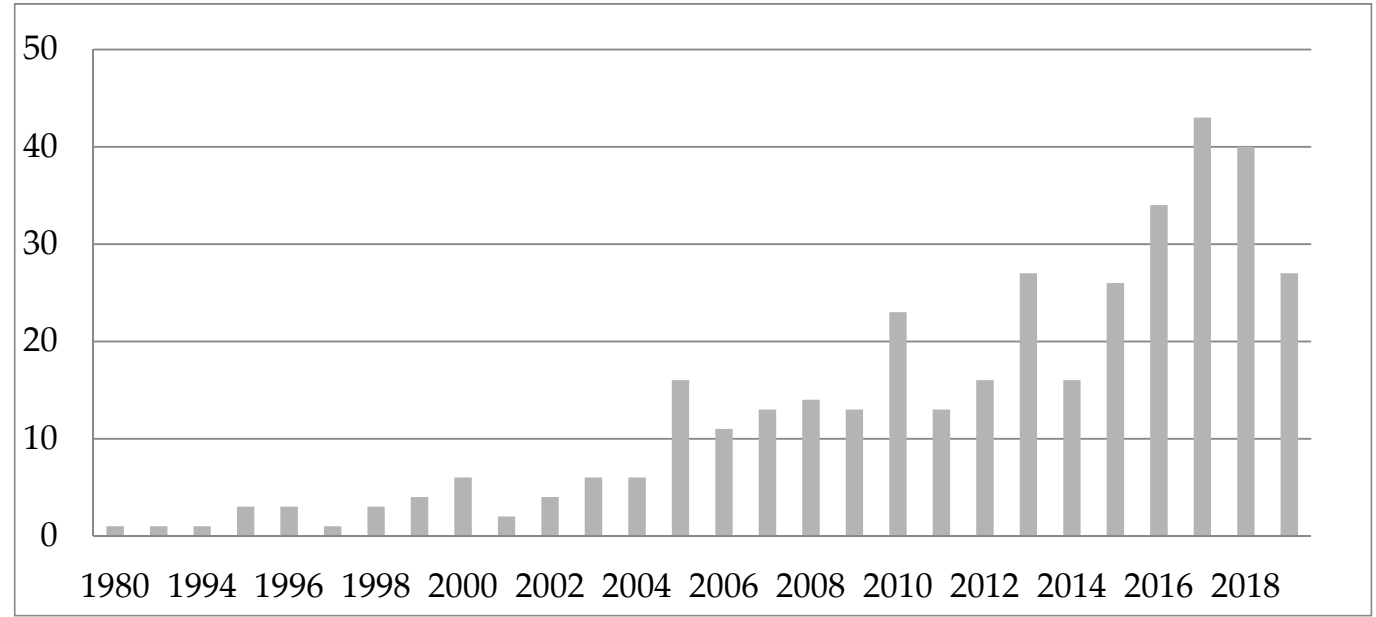

Figure 1. Publications per year.

A significant part of the publications was articles (66\%). Other publications were book chapters $(17 \%)$, reviews $(5 \%)$, books $(5 \%)$, conference papers $(3 \%)$, and other publications including editorial materials, notes, and undefined materials (3\%). The analyzed publications appeared in 110 different journals, books, conference materials, and other publications. Table 1 presents the top 10 journals with the largest number of publications. In first place for the number of published articles is Journal of Management Spirituality and Religion, the second is Leadership Quarterly, which had special issues about spiritual leadership (Vol. 16, 2005).

Table 1. The list of most numerous publications per journal.

\begin{tabular}{ccc}
\hline No & Journals & Number of Publications \\
\hline 1 & Journal of Management Spirituality and Religion & 38 \\
2 & Leadership Quarterly & 23 \\
3 & Journal of Business Ethics & 19 \\
4 & Journal of Human Values & 15 \\
5 & Purushartha & 11 \\
6 & Journal of Management Development & 9 \\
7 & Graziadio Business Report & 7 \\
8 & Journal of Organizational Change Management & 7 \\
9 & Leadership & 7 \\
10 & Contribution to Management Science & 6 \\
\hline
\end{tabular}

Source: based on Scopus (10.10.2019).

\subsection{The Clusters of the Reviewed Publications}

Cluster analysis pointed out the existence of four main clusters (Scheme 1). The first cluster is workplace spirituality (red), which is associated with 12 items such as work, values, outcomes, commitment, culture, empowerment, or paradigms. These are the most frequently discussed topics (the larger the circle of the item and the smaller the distance, the stronger relation). The second cluster (green) is leadership, which consists of 11 items such as workplace, spirituality, religion, and organization, which are the most studied. The third cluster (blue) is spiritual leadership with ten items such as performance, behavior, and servant leadership as the most discussed topics, and organizational commitment and spiritual intelligence as emerging topics. The fourth cluster (yellow) is transformational leadership with eight items. The most frequently discussed issues are ethical leadership, ethics, authentic leadership, and charismatic leadership. 


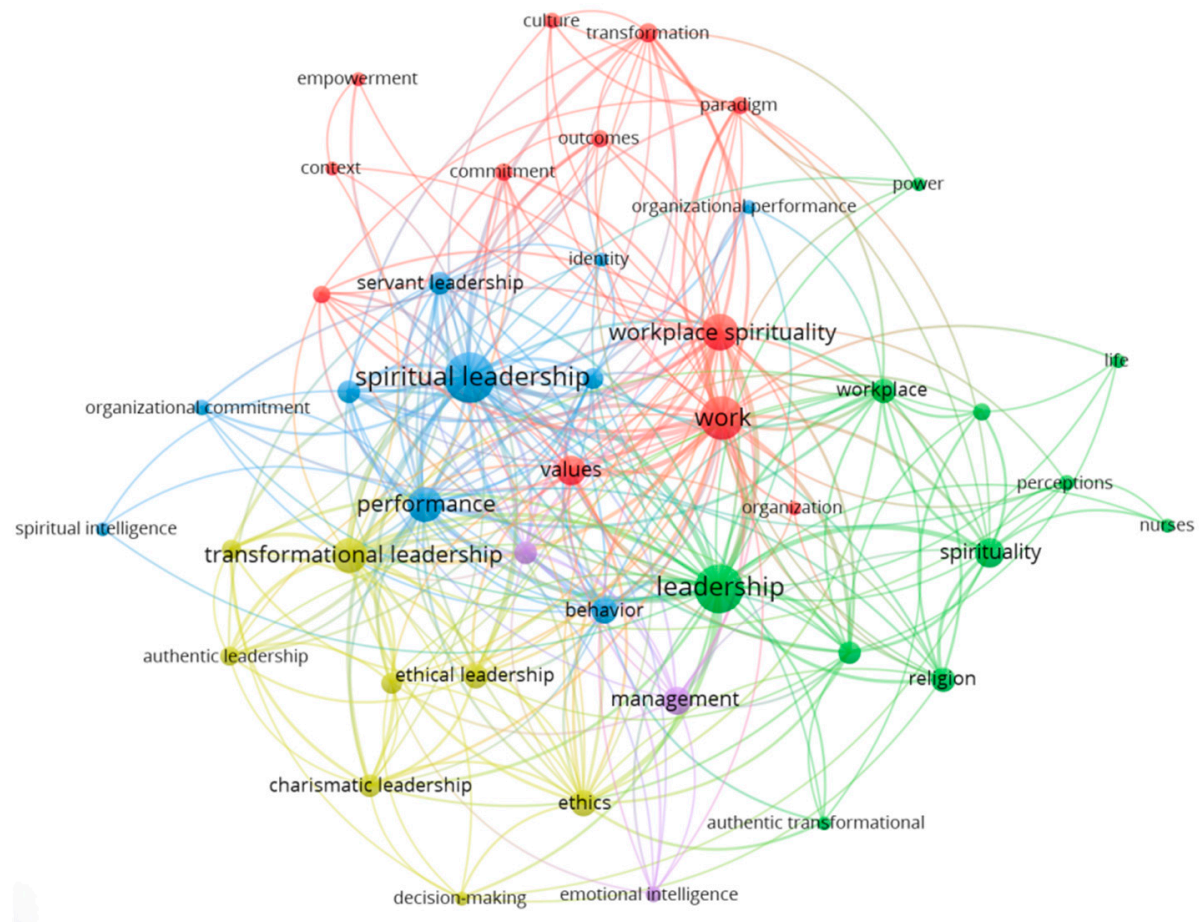

Scheme 1. The clusters of spiritual leadership publications.

The cluster analysis shows that workplace spirituality is one of the main research topics undertaken in spiritual leadership literature, with many studied trends. However, there are no terms directly related to sustainability in the workplace.

\section{Results}

\subsection{Spiritual Leadership}

Beginning from the definition of leadership, it is obvious that there are many definitions of leadership in literature. However, one important repeated characteristic can be observed in different definitions of leadership - it is an ability to motivate and inspire other people [15-19]. Many traditional leadership theories were conceptualized based on traits, behavior, abilities, or situational factors, while the theory of spiritual leadership is considered as the fifth leadership perspective that focuses attention on the whole soul nature of a leader [20]. One of the integrated definitions of leadership pointed out that leadership affects the followers to enthusiastically expend spiritual, emotional, and physical energy to achieve the organization's vision and objectives ([21], p. 7). Therefore, it can be said that the foundation of successful leadership is the ability to influence others to achieve a goal. However, the question of how can leaders influence others is still open to answers.

Before a definition of spiritual leadership can be provided, one must first explain the meaning of spirituality. The term "spirituality" has been derived from Latin word "spiritus", defined as "soul, courage, energy" [22]. Spirituality seems to be an abstract term with different meanings and has nothing to do with a sustainable workplace. However, certain definitions of spirituality can be found in management literature. One of the old definitions of spirituality emphasizes the sense of belonging to a greater whole. The others refer to the attendant feeling of interconnectedness with all things in the universe [23] or the need to be connected to something larger than ourselves, something considered as divine or of exceptional nobility [24]. Some studies indicate that the spirituality connects the human being to each other and the Earth $[25,26]$ and, in turn, facilitates the effective development of sustainability. Spirituality allows for the feeling of connection with a wider, deeper and richer whole and sees our limited situation from a holistic perspective. Astin ([27], p. 4) claimed that spirituality concerns our sense of who we are, our beliefs of why we are here-the meaning that we see in our 
work and our life-and our sense of connectedness to each other and the world around us. Many authors and researchers have pointed out the universal values of spirituality like integrity, honesty, and humility [28]; an attitude of openness, attention and consciousness [29]; love and compassion, patience, tolerance, forgiveness, contentment, personal responsibility, and a sense of harmony [30]; or search for meaning, morality, with a focus on sustainability and credibility, rooted in self-knowledge and the desire for growth and development [31]. The induction of spiritual values of interconnection and compassion leads to a harmonious living that contributes to the benefits of others, society, and nature [32]. It seems that spirituality concerns only the inner world of humans; however, our values, beliefs, experience, which are components of our spirituality, are manifested in an everyday situation-what we think, who we are, what we do, and how we behave. It influences what we speak, how we build our relationships, and even how we spend our time or money [30]. Our inner world has an impact on not only our personal life but also on our professional life-how we approach work, how we engage in activities, how we treat others in the work environment. Developing individual values of spirituality of our lives influences how we treat the world and foster our sense of connectedness to nature that results in more pro-social behaviors and our strive for social justice [33]. Although spirituality is most often viewed as naturally personal, the description of spirituality can be useful to explore how leadership can be inspired by the concept of spirituality.

The combination of spirituality and leadership indicates that certain values and attitudes like those mentioned above can have an influence on a leader's behavior towards his or her followers. The theory of spiritual leadership allows us to better understand how our internal life affects our abilities to lead others successfully [34]. Fry [34] explained that it is possible through the creation of a sense of calling for employees and a sense of purpose in what they do in order to motivate workers intrinsically by providing vision, values, hope, and loving relationships. In literature, the term "spiritual leadership" can be found; however, only a few authors gave clear definitions of this in the context of organization (Table 2).

Table 2. Definitions of spiritual leadership.

\begin{tabular}{|c|}
\hline Definition \\
\hline $\begin{array}{l}\text { The values, attitudes, and behaviors that are necessary to intrinsically motivate one's self and others so that } \\
\text { they have a sense of spiritual survival through calling and membership [34]. }\end{array}$ \\
\hline $\begin{array}{l}\text { Brings one's own search for meaning and self-awareness based on one's own spirituality into their role as a } \\
\text { leader [35]. }\end{array}$ \\
\hline An effort to involve leaders and also followers to achieve "spiritual well-being" [36]. \\
\hline $\begin{array}{l}\text { "An intimate leadership approach" that aims to create a workplace where meaningful and close relationships } \\
\text { exist among employees [37]. }\end{array}$ \\
\hline
\end{tabular}

The definitions of spiritual leadership emphasize the influence of a leader on his or her employees by creating a positive workplace. As Kouzes and Posner [17] claimed, leadership is the art of mobilizing others to want to grapple for shared aspirations. Fry and Cohen [36] proposed a very short and simple but significant enough definition-spiritual leaders involve their employees to also be "spiritual"; they share their own "spiritual well-being" with their followers so that they can have a sense of meaning and purpose. Some research have indicated that many individuals seek a way to express their spirituality through their work [35]. Spiritual leaders enable their employees to feel the part (member) of the larger whole, both universally and organizational-wise. Only in this way can employees be internally, and therefore permanently, inspired and motivated. Leaders, through emphasizing spiritual values, do not so much transform individuals as much as they awaken existing motivation [35] and change the way individuals "see" and "act" [38].

Some authors have emphasized the values of spiritual leadership. For example, Hoppe [39] claimed that spiritual leaders have the capacity to build trust and compassion. Fry [34] identified three components of spiritual leadership: vision, hope, or faith, and altruistic love. Altruistic love allows 
"the seeing of others" - not because they can do something but simply because they are humans and, as such, appreciate them. A leader who brings these values to work is able to motivate employees with regard to meaning and purpose. Asking about what it means to be human, what we really mean by growth, and what values are needed to enhance both organizations and society as a whole, are fundamental for spiritual leadership in every organization [40]. Spiritual leadership is creating a vision to experience a sense of calling, purpose, and meaning, and establishing an organizational culture based on the spiritual values in order to have a sense of membership and belonging and also to feel understood and appreciated. Workplace spirituality provides a suitable context for employees where they can feel a sense of meaningfulness and connection with others.

Spiritual leadership is especially important for leaders whose main aim is to lead people and create a sustainable workplace for employees in an organization. Ronthy ([28], p. 15) claimed that in today's world, which is characterized by changes, leaders need to find inner security to use in an external environment. Spiritual leadership is necessary for organizations to develop a clear sense of identity as individuals in workplace relationships, to know the real meaning of events and circumstances, and to identify and align employee values with a clear sense of purpose [41]. Fry and Cohen [36] stated that spiritual leadership is the ability to tap into the fundamental needs of the leader and followers; to achieve a harmony of vision and value among individuals, as well as among teams, which would, in turn, improve the well-being and organizational commitment of the employees and improve organizational performance. Spiritual leadership is considered a powerful and courageous management paradigm for the twenty-first century [42].

\subsection{Sustainability in the Workplace}

There is growing attention by both practitioners and academics about organizational sustainability. The term "sustainability" is most often associated with longevity, maintenance of core principles or purposes, and responsibility to external needs [43]. Sustainability is "development that meets the needs of the present without compromising the ability of future generations to meet their own needs" ([44], p. 8). The definitive goal of sustainable development is securing a better quality of life for all by pursuing responsible economic profitability, equitable social progress, and successful ecological protection [45] and by achieving the right balance between them. Sustainable development cannot be achieved without organizations and individuals.

Human resources as one of the main dimensions of the "triple bottom line" of firms [46] are an important challenge for implementing organizational sustainability. Human resources management needs to deepen its focus on a sustainable approach to address humans facing increasing environmental disasters, rising economic disproportion, and employees facing increasing anxiety, burnout, or employment insecurity. HR practices should respect human rights through the prevention and elimination of harassment, exploitation, and abuse of any person. According to this, HR practices should support the integration of social, environmental, and economic goals for the organization. This is possible by increasing the awareness of employees about that and developing positive attitudes toward sustainability [47] and by developing an organizational culture that embraces the sustainability paradigm $[48,49]$. Thus, human resource management is facing the challenge of creating a positive workplace environment. Organizations need to find new, sustainable practices to human resources management to support engagement every employee in organizational sustainability, which is essential for a collective approach toward achieving organizational sustainability. One of the crucial roles of human resources management is raising leaders' awareness of sustainability. Integrating sustainability with organizational systems, processes, and structures is an important task for each leader. Dissemination of an organizational vision that includes sustainability values should be one of the main responsibilities of leaders. Leaders adopting sustainability practices need to develop a wider mindset about stakeholders of the organizations and a different mindset as to the goals of organizations. Sustainability is expressed by the demonstration of appropriate organizational behaviour. Thus, a sustainable organization needs sustainable human resources. Sustainability into an 
organization requires changes in the thinking and behavior of all employees. One such way is creating a sustainable workplace.

A sustainable workplace should be created by employment practices, procedures, and policies that link employees' work-life balance and well-being, enabling them to thrive in their personal and family lives and perform well [50]. However, a sustainable workplace has the potential to affect not only employees' well-being but also an organization's success [51]. The sustainable workplace can be considered as "an environment in which people have an impact on decisions and actions that affect their jobs" ([52], p. 3). In this paper, a "sustainable workplace" is understood as a positive workplace that has a contribution to improved work-life balance, employees' well-being, involvement in ethical and social decision-making, and develops awareness of being a part of the whole (community and the world); the awareness of the connection with larger whole causes that employees are innately involved in taking care of other people, an organization, or an environment. Only in this way can employees take on social and ethical responsibility. One such way of creating a sustainable workplace may be the introduction of workplace spirituality. There is an interlink between spirituality and sustainability. It is believed that only an individual life rooted in continuous harmony with nature and based on spiritual awareness can pay attention to other people, future generations, and sustainable issues; or it is not possible for the organizations to become more sustainability without considering spirituality [53].

The significance of spirituality in the context of the workplace is a relatively new topic in management research [31,54-57]. The previous studies indicated the need for employees' experience of spirituality at work. Spirituality in the workplace has been defined as a "framework of organizational values evidenced in employees' experience of transcendence through the work process, facilitating their sense of feeling of completeness and joy" ([54], p. 13). The workplace is a key root of sustainability. Work is such an integral part of our lives that it is important to engage the whole person in the workplace [58]. However, changing environment, technology, and a highly diversified workplace has resulted in an increase in spirituality needs at the personal and organisational level. Some research has been dimensionalized components that are thought to make the workplace a more "spiritual" place. According to these studies, a spiritual workplace is commonly characterized by three dimensions: inner life, meaningful work, and community [59]. Inner life is related to a person's self-concept, which can be expressed through work [60]. Meaningful work means a deep sense of meaning in an individual's work [11]. Today, recognition of the meaning and psychological aspects of work is very important to create a sustainable workplace. Employees are searching for a work environment that allows them as spiritual entities to perform meaningful work for the betterment of the community [61]. This makes employees forcefully involved in activities with greater meaning to their lives and the lives of others [62]. A spiritual workplace provides a strong sense of alignment between the individual's personal values and the organization's mission and purpose. Community refers to the relationship of individuals with their coworkers. This dimension is based on the belief that people are connected to each other. This can motivate employees to work with integrity and purpose that is beneficial to others beyond simply doing a business [63]. Spirituality at the workplace elaborates about the one's life purpose, quality of relationships with other people associated with the workplace, harmony with one's personal beliefs, and the values of the work organization [64]. When employees have an inner life that nourishes and is nourished by meaningful work that takes place in the context of community [65], then the workplace can be considered as a sustainable place, characterized by a feeling of the meaning of work, a sense of interconnection with others, and mutually aligned individual and organizational values $[31,66,67]$. Spirituality enables people to feel alive, energized, be passionate, and care for work and people in the workplace. Workplace spirituality is the employee-friendly work environment that supports an employee's activities.

Many scholars have argued that spirituality is necessary in the sustainable workplace for the ethical attitudes of employees, life and job satisfaction and commitment, employee productivity and organizational performance, and sustainability. Organizations should place their attention beyond economic contributions. They should promote meaningful life experiences for their employees 
and society. A transition to sustainable development requires a shift from materialistic to spiritual orientation [32]. Thus, workplace spirituality can be a tool for the organization through which people experiencing some common attachment and togetherness with each other within their work unit and the organization as a whole [68].

\subsection{Significance of Spirituality in Leadership for Sustainable Workplace}

Spiritual leadership may be a significant part of the sustainable workplace. Spiritual leaders need to find a balance between their own interests, the interest of the employees, the interests of the organization, and the interest of the society. Leadership has a central role in instilling a sense of the spiritual realm in the individual, the team, and at the organizational level at work [69]. Many research studies have shown that there is a clear consistency between spiritual values and practices, according to the model of spiritual leadership proposed by Fry and Egel [59]. The model of spiritual leadership embeds sustainability into the triple bottom line (Figure 2). Personal spiritual qualities provide the foundation on which leaders may build to hone their skills and competencies to foster a sustainability mindset by seeking higher levels of consciousness, self-awareness, and other-centeredness, creating a spiritual workplace, which is essential for maximizing the triple bottom line through spiritual leadership ([59], p. 3).

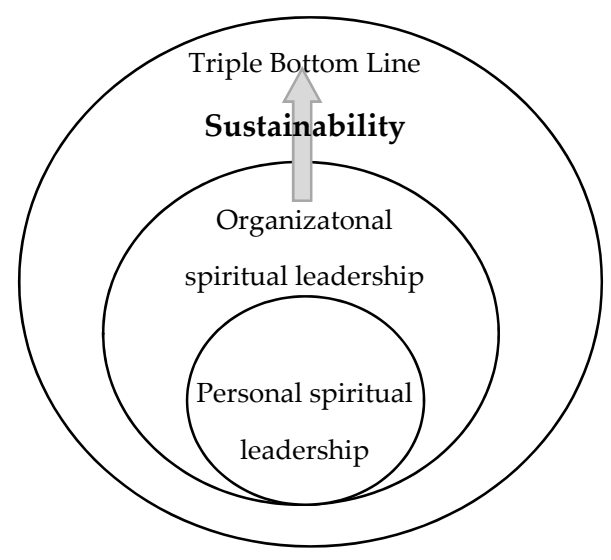

Figure 2. Model of spiritual leadership.

Research on spiritual leadership in the context of workplace measures show a number of important individual, team, and organizational benefits, as shown in Table 3. Among individual outcomes, some studies have presented that spirituality is the source of harmonizing expression of compassion, wisdom, and connectedness that transcends all egocentric, sociocentric, or anthropocentric forms [66]. Transition to sustainability requires a transition from self-centeredness to other- and nature-centeredness [32], and from materialistic management to spiritual and ethical management [70]. This, in turn, affects life satisfaction [65] and human health and well-being [71]. It is believed that today's business model focuses on the goals of egoism and the materialistic conception of man [72], which results in the increased exploitation of employees, decreased community well-being, and serious environmental decline. Spiritual leader enhances the need for connecting to others at work and to work itself [32], indicating a sense of meaning that allows one to see work as a calling rather than a job [73]. Viewing work as a calling is related to employee motivation and satisfaction, group productivity and performance, as well as leader motivation [30]. Job satisfaction has been associated with workplace satisfaction, which is one of the elements of a sustainable workplace. Moreover, some research has indicated that the more sustainable and spiritual a working environment, the less absenteeism and turnover [54,73,74]. Thus, spiritual leadership works not only by stimulating positive feelings but also by eliminating negative feelings, such as stress and fear. Employees who consider being spiritual are less fearful. Many human resources specialists often focus on symptoms of disengagement such as stress, burnout, poor 
decision-making, and high absence rates rather than the root causes. Many researchers have shown that spiritual leadership can mitigate the negative effects of job burnout [65] and counterproductive work behavior [75]. Absenteeism, job stress, and depression cost businesses billions of dollars in lost productivity [76]. This evidence has shown that a spiritual workplace leads to beneficial personal outcomes such as increased positive human health and psychological well-being and, in the bottom-line, issues of productivity as well. This leads to maintaining sustainability in the workplace. Helping workers express spiritual values in their work improves leader effectiveness in job satisfaction [77], morale, and commitment [73]. Spiritual leaders, identifying the basic needs of employees, can motivate them intrinsically by giving them faith and hope so they can be a highly committed, motivated, and productive team [31,78]. This strong intrinsic motivation provides task involvement and goal identification because it meets the higher-order needs of individuals, such as self-efficacy, a sense of autonomy, and connections [79]. Several studies have shown that these qualities are positively associated with higher levels of organizational commitment and productivity not only at an individual level but also at team level $[39,54,74,80]$. Some studies have presented that spirituality at work effects a greater sense of teamwork and community [81]. It can be assumed that employees who are committed to their organizations are probably committed to their society at large. Paying attention to society is one of the main elements of sustainability. This sense of community motivates employees to participate in citizenship behavior and care for others. Spirituality in the workplace is demonstrated by organizational citizenship behavior $[69,82]$ and has a significant influence on the performance of environmental sustainability [11]. Demonstration of social behavior by taking care of the natural environment is one of the most important manifestations of sustainable development.

Table 3. Benefits of spiritual leadership for a sustainable workplace at the individual, team and organizational levels.

\begin{tabular}{ll}
\hline \multicolumn{1}{c}{ Levels } & \multicolumn{1}{c}{ Benefits } \\
\hline & A sense of life satisfaction [65] \\
& Human health and well-being improvement [69] \\
& Greater morale, and commitment [73] \\
& A sense of meaning and calling a job [73] \\
& Greater employee and leader motivation, satisfaction, and task involvement [30,79] \\
Individual level & Self-career development, engagement, loyalty [55] \\
& Less conflict, frustration, absenteeism, turnover, and job burnout [54,55,65,70,74] \\
& Less counterproductive work behavior [75] \\
& Higher unit productivity, self-efficacy [39,54,55,74,80] \\
& A sense of autonomy, competence, and connections [79] \\
& Higher commitment and motivation [31] \\
& A sense of team and community [81] \\
& Learning in teams [83] \\
& Spiritual climate [83] \\
& Team-level innovative behaviors [83] \\
& Higher group productivity and performance [30,31,39,54,74,80] Communication \\
& improvement [81] \\
\hline Team level & Organizational learning [81] \\
& Organizational citizenship behavior [59] \\
& Higher productivity, performance excellence [31,78,84] \\
& Greater flexibility of the organization [84] \\
& Greater creativity of the organization [84] \\
& Faster growth, higher efficiency [81] \\
\hline & \\
\hline &
\end{tabular}

Some findings have indicated that spirituality influences learning in teams, spiritual climate, and team-level innovative behaviors [83]. The more humane a workplace is, the more productive, flexible, and creative the organization is [84]. This can cause an increase in high-performing teams [78]. 
These studies have proven that workplace spirituality leads to beneficial individual and organizational outcomes, and it is positively correlated with greater worker performance and delivers improved employee commitment, satisfaction, altruism, conscientiousness, engagement, loyalty, sales growth, work unit productivity and organizational citizenship behavior. On the other hand, negatively, it is related to fear, stress, burnout, conflict, frustration, earning manipulation, and instrumental commitment. It means that this might be a way to create and maintain a sustainable workplace.

The review of research about the workplace indicated that there are many studies about the positive relationship between spirituality, leadership, and followers that help build a sustainable workplace for employees. Leaders with a high level of spirituality, who care about others, pass this "spirituality" involuntarily to their employees. In turn, employee spirituality increases because they feel secure and supported. They can see a deeper sense of their tasks and notice people around them, promoting positive relationships. This creates a sustainable work environment for leaders and employees. In effect, leaders end up achieving organizational goals, higher productivity, and greater sustainability.

Before analyzing the theme of sustainable workplace in literature, it seemed that there is nothing spiritual about the workplace. However, there are many fields of the workplace in which the spirituality of a leader can be applied to improve sustainability in the organization:

- Increasing joy, peace, and happiness of employees, which positively affect job satisfaction and have a negative effect on absenteeism and turnover;

- Using spiritual consciousness to see the situations, circumstances, and problems from a holistic perspective, which results in the security and freedom of employees that, in turn, decreases the negative sides of work such as stress, depression, and job burnout;

- Engaging in moral and ethical behavior that in effect helps to make the right decisions that serve different types of stakeholders, e.g., employees, communities (local and national), future generations;

- Being inspired by vision and values, which results in a sense of meaning and purpose in work, and affects the perception of the importance of job tasks and responsibilities and commitment not only in achieving organizational goals but also in improving social well-being;

- Increasing love and trust for oneself and others, which results in building good relationships and the feeling of being part of a great community in an organization and as a whole.

These benefits of spirituality in the workplace through spiritual leadership have an impact on employees' organizational behavior, which is characterized by the awareness of higher purpose and a sense of meaning in a job, being engaged in the job responsibilities and ethical decisions, and finally being a part of society. These characteristics affect individual behavior, then an operation of the organization, and as a result, the world. A belief that an individual's current action will influence the future of society and future generations is the fundamental view of sustainability flows from spirituality. Thus, spirituality can be understood as harmony with self and the others, and with all that seem to be an external environment, although it is a part of us. Comparatively, sustainability can be understood as harmony with society and the environment. The creation and maintenance of the conditions under which humans and nature can exist in harmony is the aim of both spirituality and sustainability in the workplace and the organization. The roots of sustainability may be spirituality. Workplace spirituality contributes to sustainability through arousing a sense of meaning in life and work, a sense of community, care for others, nature, and the planet. Long ago, it was noticed in the discussion on "land ethics" that the relationship between humans with each other and toward the environment needs to take a more spiritual stand [85]. The societal shift toward sustainability requires a shift to human consciousness that is more spiritual [86]. Understanding the role of each player in society (government, unions, business, non-governmental organizations and society) and balancing global and local perspectives are basic qualities and skills of leadership for integrating social and sustainability concerns into an organization $[87,88]$. Many leaders still take the stance that 
sustainability measures can create only short-term financial benefit and cannot recognize the potential benefits of sustainability measures for overall organizational performance. Sustainability in business requires a new way of thinking about the desired results.

This leads to the proposition of the conceptual model of the impact of spiritual leadership on the sustainable workplace through spirituality in the workplace with support HRM practices and policies (Figure 3). Human resources management is a background for these three dimensions by integrating spirituality and sustainability into practices and policies. HRM raises leaders' awareness of spirituality and sustainability, develops a positive workplace environment based on spirituality, and increases awareness and attitudes of employees toward sustainability. Spiritual leadership creates a sense of calling and purpose for employees, inspires them by providing spiritual values, and builds close relationships among employees in order to develop spirituality in the workplace. A spiritual workplace ensures the creation and maintenance of positive employee behavior and attitudes at the individual (i.e., a sense of meaning and calling in a job, motivation, job satisfaction, task involvement), team (a sense of being a part of a team, team engagement), and organizational levels (a sense of being a part of an organization and the whole). Then, a spiritual workplace supports the creation and maintenance of a sustainable workplace that is expressed by individual (i.e., employee work-life balance and well-being), organizational (i.e., ethical and social responsibility), and global (i.e., caring of other people, the organization, and the environment) behavior. Only through spiritual leadership and spiritual workplace creation, can true sustainability in the workplace be achieved with the support of HRM practices and policies. Every transformation begins with an individual and spreads throughout the world. A leader should be viewed as a "living example" who nurtures the spirits of the employees instead of being "only a manager"; an organization should be viewed as a "living unit" which takes care of society and the environment instead of viewing it as "a machine for money".

\begin{tabular}{|c|c|c|}
\hline \multicolumn{3}{|c|}{$\begin{array}{l}\text { HRM practices and policies } \\
\text { reness of spirituality and sustainability } \\
\text { e workplace environment based on spirituality } \\
\text { hd attitudes of employees toward sustainability }\end{array}$} \\
\hline 1 & 1 & $I$ \\
\hline $\begin{array}{l}\text { Sustainable workplace } \\
\text { - } \quad \text { improving employee } \\
\text { work-life balance and } \\
\text { well-being } \\
\text { - commitment to ethical } \\
\text { and social } \\
\text { responsibility } \\
\text { caring for other people, } \\
\text { the organization, and } \\
\text { the environment }\end{array}$ & $\begin{array}{l}\text { Spiritual workplace } \\
\text { - } \quad \text { creating and } \\
\text { maintaining positive } \\
\text { employee behaviour } \\
\text { and attitudes at } \\
\text { individual, team and } \\
\text { organizational levels }\end{array}$ & $\begin{array}{l}\text { Spiritual leadership } \\
\text { - } \quad \text { inspiring employees } \\
\text { by providing spiritual } \\
\text { values (vision, a sense } \\
\text { of calling and } \\
\text { purpose, connection } \\
\text { to each other and a } \\
\text { larger whole) }\end{array}$ \\
\hline
\end{tabular}

Figure 3. The model of the relationships between spiritual leadership and a sustainable workplace through a spiritual workplace with supportive HRM practices and policies.

This model offers a conceptual framework of a sustainable workplace by spiritual leadership and can be a starting point for further theory development. It would be worth exploring how HRM practices 
and policies can promote spiritual leadership and a spiritual workplace, and by this, strengthen the sustainable workplace, and which variables of spiritual leadership and the spiritual workplace are the most significant for the sustainable workplace.

\section{Conclusions}

The literature review and bibliometric analysis allow the conclusion of some findings of spiritual leadership theory. This topic is relatively new. However, a growing number of research in the field of spiritual leadership in management literature indicate that it is an interesting topic, gaining more attention among scholars, and it promises to contribute significantly to the growth of more holistic and sustainable organizations.

Spiritual leadership seems to be a holistic view when compared with other theories. This concerns not only a single trait, behavior, or skill, or contextual factors like previous theories. Spirituality in leadership focuses on proceeding in accordance with universal values such as honesty, integrity, love, compassion, gratefulness that have an impact on a leader's traits, behaviors, attitudes, and abilities. The spiritual values are needed for taking responsible and ethical-meaning sustainable-activities. Following these values, it determines what we think, and who we are, what we do, and how we manage this. Spiritual leaders are successful because they do not need to change themselves or other people, situations, and organizations. They rather awaken themselves and other people through emphasizing spiritual values and, in this way, transform situations and organizations into more sustainable ones. The consciousness of interconnectedness in all things of the universe and being connected to something big allows one to take responsibility for own actions and to see the impact of these actions on others, also on future generations and the environment. This leads to making responsible and sustainable decisions. Thus, it seems that the spiritual leadership theory is worth further development in the context of sustainability.

The literature review of the topic has shown that spiritual leadership has the potential to become a highly spirited paradigm of management in today's environment that requires attention to sustainability. First of all, it is related to a lot of benefits of a spiritual leadership approach in the workplace. Workplace spirituality is one of the main developing research topics closely related to workplace sustainability. The benefits of spirituality in the workplace begin with job satisfaction, peace, commitment, feeling of a sense of job meaning and purpose, achievement goals, improved employee productivity or attainment of organizational performance, and end with social responsibility, ethical decisions, caring for others and the environment. Many researchers have reported that spiritual leadership influences society and the world. Although that has not been the subject of this study, it shows that the concept of spiritual leadership is not limited to the context of leading employees and creating a sustainable workplace.

The literature review allows a discussion about further directions for spiritual leadership theory development in the context of sustainability in the workplace. Exploring the relationship between spiritual leadership and the workplace provides many pieces of evidence about the positive influence of spiritual values and employee and organizational benefits. However, this research mainly focused on showing the positive relations between various variables. This is needed in this first stage of studying a new topic. It allowed us to determine whether this concept is important and can be applied in the context of a sustainable workplace. Now, it seems that the time has come to identify specific practices regarding the creation of a sustainable workplace by spirituality. Spirituality in the context of the workplace means harmony with self and others which, in turn, causes harmony with society and the environment; this is sustainability. Spirituality seems to be the source of sustainability; thus, a spiritual workplace seems to be the source of a sustainable workplace. This means that this concept may be further developed in order to provide a new insight into creating a sustainable workplace. The proposed model of the impact of spiritual leadership on a sustainable workplace through spirituality in the workplace and HRM practices can be a starting point for researchers for further development. The model indicates the relationships that can be further research directions on this topic. It is important to determine HRM practices that enhance spiritual leadership in order 
to create spirituality and sustainability in the workplace; it is important to explore the correlations between variables of spiritual leadership, the spiritual workplace and the sustainable workplace as well.

The development of a spiritual leadership theory as a theoretical construct seems to be relevant and applicable for creating and maintaining a sustainable workplace. Spiritual leadership is an emerging field of research, with many studies that demonstrate the need for spirituality in the workplace which is a roof of a sustainable workplace.

Funding: This research is supported by research work no. S/WIZ/1/2018 at the Bialystok University of Technology and financed from a subsidy provided by the Minister of Science and Higher Education.

Conflicts of Interest: The author declare no conflict of interest.

\section{References}

1. Crumpton, A.D. An Exploration of Spirituality within Leadership Studies Literature. Available online: http: //www.interdisciplinary.net/wpcontent/uploads/2011/02/Crumpton-paper.pdf (accessed on 10 October 2019).

2. Thompson, S. Habits of spiritually grounded leaders. Sch. Adm. 2005, 62, 26-29.

3. Millman, J.; Ferguson, J. In search of the spiritual in spiritual leadership: A case study O entrepreneur Steve Bigari. Busin. Renaiss. Q. Enhanc. Qual. Life Work 2008, 3, 19-40.

4. Crossman, J. Secular/spiritual development in education from international and global perspective. Oxford Rev. Educ. 2003, 29, 503-519. [CrossRef]

5. Daft, R.L.; Lengel, R.H. Fusion Leadership: Unlocking the Subtle Forces that Change People and Organization; Berrett-Koehler: San Francisco, CA, USA, 1998.

6. Daft, R.L. The Leadership Experience, 6th ed.; TX7: Harcourt College Publishers: San Diego, CA, USA, 2001.

7. Zsolnai, L.; Illes, K. Spiritually-inspired creativity in business. Int. J. Soc. Econ. 2017, 44, 195-205. [CrossRef]

8. Chalofsky, N.; Krishna, V. Meaningfulness, commitment, and engagement: The intersection of a deeper level of intrinsic motivation. Adv. Dev. Hum. Resour. 2009, 11, 189-203. [CrossRef]

9. Afsar, B.; Badir, Y. Workplace spirituality, perceived organizational support and innovative work behavior: The mediating effects of person-organization fit. J. Workplace Learn. 2017, 29, 95-109. [CrossRef]

10. Barron, K.; Chou, S.Y. Toward a spirituality mode of firm sustainability strategic planning processes. Soc. Bus. Rev. 2017, 12, 46-62. [CrossRef]

11. Igbal, Q.; Ahmad, B.; Ahmad, N.H. Enhancing sustainable performance through job characteristics via workplace spirituality: A study on SMEs. J. Sci. Technol. Policy Manag. 2019. [CrossRef]

12. Riaz, O.; Normore, A.H. Examining the spiritual dimension of educational leadership. J. Values Ethics Educ. Adm. 2008, 6, 1-8.

13. Ramdhani, A.; Amin, A.S.; Ramdhani, M.A. Writing a literature review research paper: A step-by-step approach. Int. J. Basic Appl. Sci. 2014, 3, 47-56.

14. Van Eck, N.J.; Waltman, L.; Dekker, R.; van der Berg, J. A comparison of two techniques for bibliometric mapping: Multidimensional scaling and VOS. J. Am. Soc. Inf. Sci. Technol. 2010, 61, 2405-2416. [CrossRef]

15. Boote, D.N.; Beile, P. Scholars before researchers: On the centrality of the dissertation literature review in research preparation. Educ. Res. 2005, 34, 3-15. [CrossRef]

16. Northouse, P.G. Leadership: Theory and Practice; Sage Publications: Thousand Oaks, NJ, USA, 2010.

17. Kouzes, J.; Posner, B. The Leadership Challenge; Josey-Bass: San Fransisco, CA, USA, 2012.

18. Zeitchik, S. 10 Ways to Define Leadership; Business News Daily: Waltham, MA, USA, 2012.

19. McDermott, A.; Kidney, R.; Flood, P. Understanding leader development: Learning from leaders. Leadersh. Organ. Dev. J. 2011, 32, 358-378. [CrossRef]

20. Fairholm, M.R. Defining Leadership A Review of Past, Present, and Future Ideas; Center for Excellence in Municipal Management: Washington, DC, USA, 2002.

21. Winston, B.E.; Patterson, K. An integrative definition of leadership. Int. J. Leadersh. Stud. 2006, 1, 6-66.

22. Simpson, D.P. Cassell's New Latin Dictionary; Funk \& Wagnalls: New York, NY, USA, 1960.

23. Fry, W.L. Spiritual Leadership; Springer International Publishing: Cham, Switzerland, 2016. [CrossRef]

24. Wigglesworth, C. SQ21: The Twenty-One Skills of Spiritual Intelligence; SelectBooks, Inc.: New York, NY, USA, 2012. 
25. Carroll, J.E. On Sustainability, Religion, and Ecology. Sustainability and Spirituality; Albany, SUNY Press: New York, NY, USA, 2004; pp. 6-20.

26. Emerich, M.M. The Gospel of Sustainability: Media, Market, and LOHAS; University of IL Press: Champaign, IL, USA, 2011.

27. Astin, H.S. Some thoughts on the role of spirituality in transformational leadership. Spiritual. Higher Educ. Newsl. 2004, 1, 1-5. Available online: http://spirituality.ucla.edu/docs/newsletters/1/Helen_Astin.pdf (accessed on 10 October 2019).

28. Ronthy, M. Leader Intelligence: How You Can Develop your Leader Intelligence with the Help of Your Soul, Heart and Mind; Amfora Future Dialogue AB: Stockholm, Sweden, 2014.

29. Roothaan, A. Spiritualiteit Begrijpen: Een Filosofische Inleading; Boom: Amsterdam, The Netherlands, 2007.

30. Delbecq, A. Christian spirituality and contemporary business leadership. J. Organ. Chang. Manag. 1999, 12, 345-349. [CrossRef]

31. Van Saane, J. Personal leadership as form of spirituality. In Leading in a VUCA World: Integrating Leadership, Discernment and Spirituality; Contributions to Management Science; Kok, J.K., van den Heuvel, S.C., Eds.; Springer: Cham, Switzerland, 2019; pp. 43-57. [CrossRef]

32. Dhiman, S.; Marques, J. Spirituality and Sustainability; Springer: Cham, Switzerland, 2016.

33. Astin, A.W.; Astin, H.S.; Lindholm, J.A.; Bryant, A.N. Spirituality in Higher Education: A National Study of College Students' Beliefs and Values; Higher Education Research Institute: Los Angeles, CA, USA, 2005.

34. Fry, J.W. Toward a theory of spiritual leadership. Leadersh. Q. 2003, 14, 693-727. [CrossRef]

35. Reave, L. Spiritual values and practices related to leadership effectiveness. Leadersh. Q. 2005, 16, 655-687. [CrossRef]

36. Fry, L.W.; Cohen, M.P. Spiritual leadership as a paradigm for organizational transformation and recovery from extended work hour cultures. J. Bus. Ethics 2009, 84, 265-278. [CrossRef]

37. Aslan, M.; Korkut, A. Spiritual leadership in primary schools in turkey. J. Educ. Soc. Res. 2015, 5, 123-136. [CrossRef]

38. Modaff, D.; Dewine, S.; Butler, J. Organizational Communication: Foundations, Challenges and Misunderstandings; Pearson/Allyn \& Bacon: Boston, MA, USA, 2008.

39. Hoppe, S. Spirituality and leadership. New Dir. Teach. Learn. 2005, 4, 83-92. [CrossRef]

40. Fry, L.W. Toward a theory of ethical and spiritual well-being and corporate responsibility through spiritual leadership. In Positive Psychology in Business Ethics and Corporate Responsibility; Gialcone, R.A., Jurkiewicz, C.L., Eds.; Information Age Publishing: Greenwich, UK, 2005.

41. Selver, P. Spiritual Values in Leadership and the Effects on Organizational Performance: A Literature Review; University of Northern British Columbia: Prince George, BC, Canada, 2013.

42. Crossman, J. Conceptualising spiritual leadership in secular organizational contexts and its relation to transformational, servant and environmental leadership. Leadersh. Organ. Dev. J. 2010, 31, 596-608. [CrossRef]

43. Bateh, J.C.; Heaton, C.; Arbogast, G.W. Defining sustainability in the business setting. Am. J. Bus. Educ. 2013, 6, 397-400. [CrossRef]

44. World Commission on Environment and Development. Our Common Future; Oxford University Press: Oxford, UK, 1987.

45. Cavagnaro, E.; Curiel, G. Three Levels of Sustainability; Greenleaf Publishing: Sheffield, UK, 2012.

46. Hart, S.L.; Milstein, M.B. Creating sustainable value. Acad. Manag. Exec. 2003, 17, 56-69. [CrossRef]

47. Garavan, T.; McGuire, D. Human resource development and society: Human resource development's role in embedding corporate social responsibility, sustainability, and ethics in organizations. Adv. Dev. Hum. Res. 2010, 12, 487-507. [CrossRef]

48. Liebowitz, J. The role of HR in achieving a sustainability culture. J. Sustain. Dev. 2010, 3, 50-57. [CrossRef]

49. Rimanoczy, I.; Pearson, T. Role of HR in the new world of sustainability. Ind. Commer. Train. 2010, 42, 11-17. [CrossRef]

50. Kossek, E.; Valcour, M.; Lirio, P. The sustainable workforce: Organizational strategies for promoting work-life balance and wellbeing. In Work and Wellbeing: Wellbeing: A Complete Reference Guide, III; Chen, P.Y., Cooper, C.L., Eds.; John Wiley \& Sons, Inc.: Hoboken, NJ, USA, 2014; pp. 295-319. [CrossRef]

51. Nollman, M.R. Sustainability Initiatives in the Workplace and Employee Productivity. Research Papers, 2013. Paper 441. Available online: http://opensiuc.lib.siu.edu/gs_rp/441 (accessed on 20 November 2019). 
52. Quagraine, T.L. Employee Involvement as an Effective Management Tool in Decision-Making: A Case Study of Merchant Bank. 2015. Available online: http://ir.knust.edu.gh/bitstream/1 (accessed on 3 December 2019).

53. Stead, J.G.; Stead, W.E. Building spiritual capabilities to sustain sustainability-based competitive advantages. J. Manag. Spiritual. Relig. 2014, 11, 143-158. [CrossRef]

54. Dehler, G.E.; Welsh, M.A. The experience of work: Spirituality and the new workplace. In Handbook of Workplace Spirituality and Organizational Performance; Giacalone, R.A., Jurkiewicz, C.L., Eds.; M.E. Sharp. Inc.: New York, NY, USA, 2003; pp. 46-56.

55. George, M. Practical application of spiritual intelligence in the workplace. Hum. Resour. Manag. Int. Dig. 2006, 14, 3-5. [CrossRef]

56. Benefiel, M.; Fry, L.W.; Geigle, D. Spirituality and religion in the workplace: History, theory, and research. Psychol. Relig. Spiritual. 2014, 6, 175-187. [CrossRef]

57. Giacalone, R.A.; Jurkiewicz, C.L. Toward a science of workplace spirituality. In Handbook of Workplace Spirituality and Organizational Performance; Giacalone, R.A., Jurkiewicz, C.L., Eds.; M.E. Sharp. Inc.: New York, NY, USA, 2003; pp. 3-28.

58. Lips-Wiersma, M.; Morris, L. Discriminating between "meaningful work" and the management of meaning. J. Bus. Ethics 2009, 88, 491-511. [CrossRef]

59. Fry, L.; Egel, E. Spiritual Leadership: Embedding Sustainability in the Triple Bottom Line; Graziadio Business Review; Graziadio School of Business and Management Pepperdine University: Malibu, CA, USA, 2017; Available online: https://www.researchgate.net/publication/322150882 (accessed on 10 October 2019).

60. Duchon, D.; Plowman, D.A. Nurturing the spirit at work: Impact on work unit performance. Leadersh. Q. 2005, 16, 807-833. [CrossRef]

61. Gupta, M.; Kumar, V.; Singh, M. Creating satisfied employees through workplace spirituality: A study of the private insurance sector in Punjab (India). J. Bus. Ethics 2014, 122, 79-88. [CrossRef]

62. Ashmos, D.; Duchon, D. Spirituality at work: A conceptualization and measure. J. Manag. Inq. 2000, 9, 134-145. [CrossRef]

63. Van Dierendonck, D. The construct validity of Ryff's scales of psychological well-being and its extension with spiritual well-being. Personal. Individ. Differ. 2004, 36, 629-643. [CrossRef]

64. Iqbal, Q.; Hassan, S.H. Role of workplace spirituality: Personality traits and counterproductive workplace behaviors in banking sector. Int. J. Manag. Account. Econ. 2016, 3, 806-821.

65. Hunsaker, W.D. Spiritual leadership and organizational citizenship behavior: Relationship with Confucian values. J. Manag. Spiritual. Relig. 2016, 13, 206-225. [CrossRef]

66. Yang, M.; Fry, L.W. The role of spiritual leadership in reducing healthcare worker burnout. J. Manag. Spiritual. Relig. 2018, 15, 305-324. [CrossRef]

67. Maxwell, T.P. Integral spirituality, deep science, and ecological awareness. J. Relig. Sci. 2003, 38, $257-276$. [CrossRef]

68. Harrington, W.J.; Preziosi, R.C.; Gooden, D.J. Perceptions of workplace spirituality among professionals and executives. Empl. Responsib. Rights J. 2001, 13, 155-163. [CrossRef]

69. Cacioppe, R. Creating spirit at work: Re-visioning organization development and leadership-Part, I. Leadersh. Organ. Dev. J. 2000, 21, 48-54. [CrossRef]

70. Zsolnai, L. Post-Materialistic Business: Spiritual Value-Orientation in Renewing Management; Palgrave: New York, NY, USA, 2015.

71. Khanna, H.; Srinivas, E. Spirituality and Leadership Development; Presented to the Roundtable Conference on Developing Leaders, Teams, and Organizations: Meeting the Challenges of Global Markets and Technology; Management Development Institute: Guragon, India, 2000.

72. Paloutzian, R.F.; Emmons, R.A.; Keortge, S.G. Spiritual well-being, spiritual intelligence, and healthy workplace policy. In Handbook of Workplace Spirituality and Organizational Performance; Giacalone, R.A., Jurkiewicz, C.L., Eds.; M.E. Sharp. Inc.: New York, NY, USA, 2003; pp. 123-137.

73. Fry, L.W.; Vitucci, S.; Cedillo, M. Spiritual leadership and army transformation: Theory, measurement, and establishing a baseline. Leadersh. Q. 2005, 16, 835-862. [CrossRef]

74. Hunsaker, W.D.; Nam, J.G. Counterproductive work behavior: Mitigating role of spiritual leadership. Adv. Sci. Lett. 2017, 23, 1656-1659. [CrossRef]

75. Eisler, R.; Montouri, A. The human side of spirituality. In Handbook of Workplace Spirituality and Organizational Performance; Giacalone, R.A., Jurkiewicz, C.L., Eds.; M.E. Sharp. Inc.: New York, NY, USA, 2003; pp. 46-56. 
76. Jeon, K.S.; Passmore, D.L.; Lee, C.; Hunsaker, W. Spiritual leadership: A validation study in a Korean context. J. Manag. Spiritual. Relig. 2013, 10, 342-357. [CrossRef]

77. Fry, L.W.; Nisiewicz, M. Maximizing the Triple Bottom Line Through Spiritual Leadership; Stanford Business Books: Stanford, CA, USA, 2013.

78. Bodla, M.A.; Ali, H. Workplace spirituality: A spiritual audit of banking executives in Pakistan. Afr. J. Bus. Manag. 2012, 6, 3888-3897.

79. Hernández López, L.; Ramos Ramos, R.; Ramos Ramos, S. Spiritual behaviour in the workplace as a topic for research. J. Manag. Spiritual. Relig. 2009, 6, 273-285. [CrossRef]

80. Pandey, A.; Gupta, R.K.; Arora, A.P. Spiritual climate inventory. In Pfeiffer Annual for Consulting; Biech, E., Ed.; Pfeiffer, Imprint of Wiley: San Francisco, CA, USA, 2009; pp. 115-126.

81. Zellers, K.L.; Perrewe, P.L. Handbook of Workplace Spirituality and Organizational Performance; Giacalone, R.A., Jurkiewicz, C.L., Eds.; M.E. Sharp. Inc.: New York, NY, USA, 2003; pp. 300-313.

82. Kazemipour, F.; Mohamad, A.S.; Pourseidi, B. Relationship between workplace spirituality and organizational citizenship behavior among nurses through mediation of affective organizational commitment. J. Nurs. Scholarsh. 2012, 44, 302-310. [CrossRef]

83. Ritter, R.A. Infusing traditional business systems with spiritual wisdom: How mindfulness improves organizational effectiveness. Graziadio Bus. Rep. 2014, 17, 1-13.

84. Yang, F.; Huang, X.; Wu, L. Experiencing meaningfulness climate in teams: How spiritual leadership enhances team effectiveness when facing uncertain tasks. Hum. Resour. Manag. 2019, 58, 155-168. [CrossRef]

85. Leopold, A. A Sand County Almanac; Random House: New York, NY, USA, 1949.

86. Schumacher, E.F. Small Is Beautiful: Economics as if People Mattered; Harper \& Row: New York, NY, USA, 1973.

87. Wilson, A.; Holton, V. Changing Manager Mindsets-Report of the Working Group on the Development of Professional Skills for the Practice of Corporate Social Responsibility; Department of Trade and Industry/The Corporate Responsibility Group: London, UK, 2003.

88. Hind, P.; Wilson, A.; Lenssen, G. Developing leaders for sustainable business. Corp. Gov. Int. J. Bus. Soc. 2009, 9, 7-20. [CrossRef] 